\title{
Sekvenciranje naslednje generacije pri obravnavi otrok $z$ akutno limfoblastno levkemijo
}

\section{Next-generation sequencing in pediatric acute lymphoblastic leukemia}

Klementina Črepinšek, Maruša Debeljak, Janez Jazbec

\section{Izvleček}

Akutna limfoblastna levkemija (ALL) je genetsko zelo heterogena bolezen in tudi ena najbolje raziskanih. Kljub temu je naše razumevanje, kako genetske spremembe sodelujejo pri nastanku levkemije ali odpornosti na zdravljenje, še vedno pomanjkljivo. Še vedno ostajajo določeni podtipi z izjemno slabimi izidi zdravljenja, saj se bolezen pri kar $20 \%$ bolnikov ponovi in večina ne preživi. Novi pristopi v diagnosticiranju ALL, ki temeljijo na uporabi metod sekvenciranja naslednje generacije, prinašajo nove možnosti za boljše razumevanje razvoja bolezni, opredelitev novih podtipov bolezni in boljše ocenjevanje tveganja. Omogočajo tudi spremljanje klonalne dinamike med zdravljenjem in ob relapsu, kar odpira nove možnosti za boljšo obravnavo bolnikov z relapsom ALL. Prav tako lahko s temi metodami natančneje spremljamo odziv na zdravljenje in prepoznavamo nove potencialne tarče za bolj usmerjeno zdravljenje.

Ključne besede: akutna limfoblastna levkemija, sekvenciranje naslednje generacije, relaps, minimalni preostanek bolezni. 


\section{Uvod}

Akutna limfoblastna levkemija (ALL) je rak krvnih celic in kostnega mozga ter predstavlja kar četrtino vseh rakavih bolezni pri otrocih (1). V Sloveniji za ALL zboli povprečno 13 otrok na leto (2). Do razvoja ALL pride zaradi maligne preobrazbe limfoblastov, ki ohranijo sposobnost delitve, a izgubijo sposobnost dozorevanja v zrele limfocite B oz. T. V kostnem mozgu se pretirano namnožijo blasti, ki izpodrinejo zdrave celice, zato pride do oviranja normalne hematopoeze (3).

Postavitev diagnoze ALL temelji na anamnezi, kliničnem pregledu in različnih laboratorijskih preiskavah. Opravimo osnovne laboratorijske preiskave, kot so hemogram in biokemijske preiskave. Pri vsakem bolniku opravimo tudi citomorfološki pregled aspirata kostnega mozga in s pretočno citometrijo določimo imunofenotip (B-celična akutna limfoblastna levkemija (B-ALL) ali T-celična akutna limfoblastna levkemija (T-ALL)). Sledijo citogenetske preiskave (analiza kariotipa in fluorescenčna hibridizacija in situ (FISH)) in molekularnogenetske preiskave (obratna transkripcija in verižna reakcija s polimerazo (angl. reverse transcription polymerase chain reaction, RT-PCR), od ligacije odvisno hkratno pomnoževanje sond (angl. multiplex ligation-dependent probe amplification, MLPA)). Z RT-PCR določamo nekatere genske preureditve, ki lahko narekujejo zdravljenje, z MLPA pa ugotavljamo večje delecije in duplikacije $v$ posameznih genih $(3,4)$.

ALL imunofenotipsko delimo na B-celično ALL, ki je pogostejša (70-75\%), in T-celično ALL (15-25\%). B-ALL nadalje razvrstimo glede na citogenetske nepravilnosti, in sicer na B-ALL brez določene opredelitve in B-ALL $s$ ponavljajočimi se genskimi nepravilnostmi. Med slednje uvrščamo anevploidije, kromosomske translokacije, ki deregulirajo onkogene ali zapisujejo himerne transkripcijske faktorje, ter delecije, amplifikacije in točkovne genetske spremembe (5). Med pediatričnimi bolniki z B-ALL sta najpogostejši hiperdiploidnost in prisotnost translokacije $\mathrm{t}(12 ; 21)$ [ETV6-RUNX1], ki sta napovedno tudi najbolj ugodni. Spremembe s slabim napovednim pomenom so translokacija $\mathrm{t}(9 ; 22)$ [BCR-ABL1], preureditve gena $K M T 2 A$ in hipodiploiden kariotip. Bolnike s translokacijo $t(1 ; 19)$ [TCF3-PBX1] in bolnike brez sprememb kariotipa uvrščamo v skupino $z$ vmesnim tveganjem (6).

Pri T-ALL so najpogosteje prisotne genetske spremembe, ki vplivajo na tri signalne poti, in sicer na izražanje T-linijskih transkripcijskih faktorjev, med katerimi so pogoste spremembe v genih TAL1, TAL2, TLX1, HOXA, LMO1/ LMO2 (7-9), signaliziranje NOTCH1/ MYC, pri čemer gre najpogosteje za izkrivljeno aktivacijo transkripcijskega faktorja NOTCH1 $(10,11)$, in regulacijo celičnega cikla, pri kateri največkrat najdemo delecije na tumorsupresorskem lokusu. Običajno so prisotne delecije CDKN2A/CDKN2B, redkeje tudi CDKN1B, RB1 ali CCND3 (9).

Poseben podtip T-ALL je limfoblastna levkemija z zgodnjimi prekurzorji T-celic (angl. early T-cell precursor ALL, ETP-ALL). Zanjo je značilen poseben imunofenotip (znižano ali odsotno izražanje T-celičnih označevalcev CD1a, CD8 in CD5 ter izkrivljeno izražanje mieloidnih označevalcev in označevalcev matičnih celic), genetsko pa je zelo heterogena (12). Pogosto so prisotne spremembe $v$ genih, ki so pomembni za hematopoetski in limfoidni razvoj (RUNX1, IKZF1, ETV6, GATA3, EP300), genih, vpletenih $v$ signaliziranje preko citokinskih receptorjev in poti Ras (NRAS, KRAS, JAK1, JAK2, PTPN11), ter genih, povezanih s kromatinskimi modifikacijami (PRC2, SETD2) $(13,14)$.

Na razvoj ALL vplivajo številni dejavniki, med katere uvrščamo podedovane genetske spremembe, primarne (iniciacijske) spremembe in sekundarne genetske spremembe. Podedovane genetske spremembe so odgovorne za večjo nagnjenost k razvoju bolezni, primarne in sekundarne spremembe pa vodijo do motenj v številnih celičnih poteh in s tem do motenj v razvoju limfoidnih celic. Do relapsa bolezni pride zaradi selekcije levkemičnih subklonov ali pridobitve novih genetskih sprememb, ki zagotavljajo odpornost na zdravljenje (15).

\section{Novejši pristopi pri diagnosticiranju ALL}

$\mathrm{Na}$ izid zdravljenja pomembno vpliva razvrstitev bolnikov glede na genetske in molekularnogenetske značilnosti. Zahvaljujoč vedno boljšemu razvrščanju bolnikov glede na stopnjo tveganja in novim pristopom zdravljenja lahko danes pozdravimo večino otrok z ALL, saj je petletno celokupno preživetje teh bolnikov v razvitih državah višje od $80 \%(16,17)$. Kljub velikemu napredku pri zdravljenju ALL imajo nekateri podtipi bolezni še vedno slabo napoved izida bolezni. Pri 10-20\% teh bolnikov se bolezen ponovi $(1,18)$, relapse pa pogosto spremljajo odpornost na kemoterapijo, neuspešno zdravljenje in smrt. Prav tako s standardnimi diagnostičnimi testi pri približno četrtini bolnikov ne najdemo nobenih genetskih sprememb, ki bi lahko bolje usmerile zdravljenje. Ker zgolj povečevanje intenzivnosti obstoječih protokolov zdravljenja verjetno ne bo izboljšalo njihove učinkovitosti, ampak le povečalo pojavnost neželenih učinkov, ostaja izjemno pomembno iskanje novih diagnostičnih in prognostičnih meril, ki bodo pomagala usmerjati individualizirano zdravljenje (19). Uporaba genomskih in transkriptomskih analiz ima izjemen pomen pri razumevanju patogeneze in pomemben prognostični učinek. S transkriptomsko analizo vzorca RNK bolnika z ALL lahko ugotovimo pomembna neravnovesja, ki vplivajo na delovanje maligno spremenjene celice, s sekvenciranjem posameznih celic pa lahko dobimo vpogled $v$ intratumorsko heterogenost, ki je pogosto vzrok neuspešnega zdravljenja (20). 


\section{Sekvenciranje naslednje generacije}

Sekvenciranje naslednje generacije (angl. next generation sequencing, NGS) je tehnologija, s katero določamo nukleotidno zaporedje več milijonov kratkih fragmentov DNK hkrati. To omogoča hitrejše določanje nukleotidnega zaporedja z manjšimi stroški v primerjavi s konvencionalnim sekvenciranjem po Sangerju. Z NGS lahko tudi odkrivamo mnogo večji spekter sprememb, med njimi substitucije, insercije, delecije, velike genomske delecije eksonov ali celotnih genov ter tudi inverzije in translokacije (21).

Tehnike NGS omogočajo analizo celotnega genoma (angl. whole genome sequencing, WGS), celotnega eksoma (angl. whole exome sequencing, WES) in celotnega transkriptoma (angl. whole transcriptome sequencing, WTS), lahko pa izvajamo tudi sekvenciranje tarčnih genov. Tehnika WES je uporabna predvsem za odkrivanje točkovnih genetskih sprememb, medtem ko WGS uporabljamo tudi za odkrivanje strukturnih sprememb in sprememb v številu kopij (angl. copy number variation, CNV). Sekvenciranje RNK lahko uporabljamo za analizo mRNK, s katero lahko analiziramo profil izraženih genov $v$ celicah in prepoznavamo prisotnost genetskih sprememb $v$ zaporedju ter prisotnost zlitih genov, in tudi nekodirajočih RNK (npr. miRNK). Za rutinsko uporabo v diagnosticiranju je najbolj smiselno sekvenciranje tarčnih genov $(20,21)$.

Glavni koraki pri sekvenciranju so osamitev DNK ali RNK iz izhodnega vzorca, priprava knjižnice, sekvenciranje in na koncu bioinformatična obdelava podatkov. Za analiziranje sprememb pri ALL DNK oz. RNK izoliramo iz celic kostnega mozga, lahko tudi iz periferne krvi. Priprava knjižnice se začne s fragmentacijo nukleinskih kislin. Če želimo analizirati RNK, moramo $v$ naslednjem koraku z reakcijo obratnega prepisovanja sintetizirati komplementarno DNK (cDNK). Sledi poravnavanje visečih koncev ter dodajanje adapterskih in indeksnih sekvenc na DNK. V nadaljevanju sledita čiščenje in izolacija fragmentov določene dolžine, nato pa se ti fragmenti DNK preko adapterjev vežejo na pretočno celico, kjer se z reakcijo PCR knjižnica DNK pomnoži. Sledita sekvenciranje in obdelava podatkov. Obstaja več različnih platform NGS, ki uporabljajo različne tehnologije sekvenciranja. Za obdelavo podatkov je na voljo ogromno različnih programov in metod, glavni koraki v postopku pa so procesiranje slike in generiranje odčitkov zaporedja, ocena kakovosti odčitkov, poravnava odčitkov na referenčni genom, identifikacija različic, anotacija različic in vizualizacija $(22,23)$.

\section{Sekvenciranje RNK}

Sekvenciranje RNK pri bolnikih z ALL je omogočilo boljše razumevanje patogeneze bolezni in vodilo do odkritja novih gonilnih genetskih sprememb in sprememb v izražanju ključnih genov v limfoidnem razvoju tudi pri tistih bolnikih, pri katerih standardne diagnostične metode niso pokazale anomalij. To je vodilo do opredelitve novih genetskih podtipov ALL in boljše ocene tveganja za te bolnike. Sekvenciranje RNK vedno pogosteje uporabljamo tudi pri spremljanju odziva na zdravljenje in spremljanju toksičnosti zdravljenja (24).

Izsledki dosedanjih raziskav kažejo, da ima uporaba sekvenciranja RNK velik potencial v diagnosticiranju ALL, saj lahko s tem pristopom poleg vseh novoodkritih genetskih sprememb zaznamo tudi večino sprememb (prisotnost najpogostejših translokacij), ki jih zdaj določamo z drugimi metodami (analiza kariotipa, FISH, RT-PCR). Vendar ima sekvenciranje RNK še vedno nekaj omejitev, saj ne moremo zaznati sprememb v vzorcih, ki imajo nizek delež tumorskih celic, ali v vzorcih z nizkim izražanjem spremenjenih genov. Rešitev je povečanje pokritosti sekvenciranja, kar pa pomeni tudi višjo ceno preiskav. Dodatna težava je zaznavanje preureditev v promotorskih in ojačevalnih regijah, ki jih s sekvenciranjem RNK neposredno ne moremo zaznati. $V$ teh primerih lahko spremembe zaznamo posredno preko prepoznavanja povečanega izražanje tarčnih genov $(24,25)$.

Tarčno sekvenciranje RNK z reagentnim kompletom Archer ${ }^{\circledR}$ FusionPlex ${ }^{\circledR}$ Acute Lymphoblastic Leukemia

$\mathrm{Na}$ trgu se pojavlja vedno več komercialnih reagentnih kompletov za pripravo knjižnic, ki omogočajo tarčno sekvenciranje RNK. Takšen pristop je najprimernejši za rutinsko uporabo v diagnostičnih laboratorijih, saj je tarčno sekvenciranje v primerjavi z WTS hitrejše in cenejše ter tudi bolj občutljivo, ker s posebno obliko reakcije PCR (angl. anchored multiplex PCR, AMP) obogatimo tiste gene, ki nas zanimajo $(26,27)$. Eden takšnih kompletov je tudi komplet $\operatorname{Archer}^{\circledR}{ }^{\circledR}$ usionPlex ${ }^{\circledR}$ Acute Lymphoblastic Leukemia, ki vsebuje 506 oligonukleotidnih začetnikov, specifičnih za 81 genov, ki so pri ALL pogosto spremenjeni. Komplet omogoča zaznavo znanih in neznanih fuzijskih partnerjev, točkovnih genetskih sprememb in ravni izražanja genov. Prepoznava neznanih fuzijskih partnerjev je zlasti pomembna in uporabna pri zaznavi preureditev $K M T 2 A$ in raznolikih preureditev, prisotnih pri podtipih $B C R$-ABL1-podobna ALL in PAXalt $(26,28)$. V primerjavi z drugimi paneli, ki so trenutno na voljo za preučevanje malignih bolezni, ta najbolje pokriva gene, pomembne pri ALL. Prednost uporabe tega panela $v$ rutinskem diagnosticiranju je tudi proizvajalčeva programska oprema, ki omogoča enostavno obdelavo podatkov, vendar komplet ne pokriva določenih genov, ki igrajo ključno vlogo pri ALL, kot so TP53, CSF1R in NF1. Izkazalo se je tudi, da $z$ uporabo tega panela ne zaznamo določenih sprememb, ki smo jih prepoznali s standardnimi diagnostičnimi metodami. Za zaznavo sprememb v teh genih je zato potrebna uporaba drugih metod. Rezultati oz. spremembe, ki jih uspemo zaznati, se lahko razlikujejo tudi zaradi uporabe različnih platform za sekvenciranje in obdelavo podatkov. Če za sekvenciranje uporabimo platformo Illumina, za obdelavo podatkov 
pa programsko opremo Archer ${ }^{\circ}$, lahko zaznamo točkovne spremembe, medtem ko platforma lonTorrent in programska oprema lonReporter tega ne omogočata, kar moramo upoštevati pri uvedbi metode v laboratorij (26-28).

\section{Novi genetski podtipi otroške ALL}

\section{Novi genetski podtipi otroške \\ B-ALL}

Genomske analize, predvsem sekvenciranje transkriptoma, so vodile do odkritja novih genetskih podtipov B-ALL, ki jih do sedaj s standardnimi diagnostičnimi metodami nismo prepoznali zaradi prisotnosti kriptičnih preureditev ali drugih sprememb, ki delujejo kot gonilne genetske spremembe. Mednje uvrščamo tudi preureditve genov DUX4, MEF2D in ZNF384, ki skupaj predstavljajo 9-16 \% vseh primerov otroških B-ALL. Vsi trije geni kodirajo zapise za transkripcijske faktorje, njihovo deregulirano izražanje, ki je posledica translokacij s številnimi različnimi partnerskimi geni, pa sodeluje pri razvoju B-ALL. Preureditve gena DUX4 so napovedno ugodne, ZNF384 vmesne, MEF2D pa neugodne $(29,30)$.

Eden najpogosteje spremenjenih genov je gen PAX5, ki zapisuje protein, ki deluje kot transkripcijski aktivator, specifičen za nezrele celice B. Spremembe v tem genu se pojavljajo pri približno 40 $\%$ bolnikov. $V$ novejših raziskavah so opredelili dva nova podtipa z vmesnim tveganjem, ki imata specifične spremembe v genu PAX5, in sicer PAX5alt, za katerega so značilne preureditve, intragenske amplifikacije in točkovne genetske spremembe v genu PAX5 in je prisoten pri približno $10 \%$ bolnikov, ter PAX5 P80R, ki je prisoten pri približno 4 $\%$ bolnikov (31).

Še en pogosto mutiran gen pri otroški B-ALL je IKZF1, ki kodira zapis za transkripcijski faktor IKAROS. Delecije v IKZF1 so prisotne pri približno 15
$\%$ bolnikov in so povezane z neugodno napovedjo izida bolezni, saj so med najpomembnejšimi napovednimi dejavniki za relaps $(32,33)$. Opredelili so tudi nov prognostični profil, ki ima posebej neugodno napoved izida, in sicer $I K Z F 1^{\text {plus }}$. Zanj sta poleg delecij v IKZFI značilni prisotnost še vsaj ene delecije v genih CDKN2A, CDKN2B, PAX5 ali v regiji PAR1 in hkrati odsotnost delecije gena $E R G$ (34).

$Z$ analizo profila izraženih genov so $v$ zadnjih letih opredelili tudi več novih podtipov ALL, za katere je značilna prisotnost zelo raznolikih sprememb na genski ravni, opredeljuje pa jih profil izraženih genov, ki je podoben profilom že znanih podtipov B-ALL. Mednje uvrščamo ETV6-RUNX1-podobno ALL, $B C R$-ABL1-podobno ALL, KMT2A-podobno ALL in ZNF384-podobno ALL (31, 35, 36). ETV6-RUNX1-podoben profil se pojavlja pri približno $3 \%$ pediatričnih B-ALL in je prognostično ugoden, medtem ko $B C R$-ABL1-podoben profil najdemo pri približno $10 \%$ bolnikov in ima manj ugodno napoved izida, a so se izidi zdravljenja za te bolnike, podobno kot za bolnike z $B C R$ - $A B L 1$-pozitivno ALL, bistveno izboljšali z uporabo zaviralcev tirozin kinaz. Druga dva podtipa sta zelo redka $(<1 \%)$ in zato tudi njun prognostični pomen še ni povsem jasen $(31,35,37)$.

\section{Novi genetski podtipi otroške T-ALL}

T-ALL je manj pogosta ALL, za katero so prav tako značilne raznolike genetske spremembe. S tehnologijo NGS so $v$ zadnjih letih pri T-ALL odkrili številne nove genetske spremembe $v$ transkripcijskih faktorjih (DNM2, RELN, FAT1, NR4A1, CTCF, MYB), epigenetskih regulatorjih (KMT2D, DNMT3A, EZH2) ter genih, povezanih z različnimi signalnimi potmi (PAK4, MINKI) in uravnavanjem celičnega cikla (BOD1L1, VCP, CCND3) $(9,38-40)$.

Poleg sprememb v kodirajočih regijah so z uporabo WGS in sekvenciranja RNK odkrili tudi več sprememb v neko- dirajočih regijah, predvsem na lokusih LMO1, LMO2 in TAL1, ki nosijo zapise za transkripcijske regulatorje, ki so odgovorni za diferenciacijo timocitov (41). Nove tehnologije so omogočile tudi prepoznanje 18 novih zlitih genov, povezanih S T-ALL, med katerimi so se trije pojavili pri več bolnikih (ZBTB16-ABL1, TRA-SALL2 in NKX2-1) (40).

\section{Uporaba NGS pri relapsu ALL}

Relaps ALL je še vedno eden glavnih vzrokov otroških smrti, povezanih z rakom (42). Zanj je značilna odpornost na kemoterapijo, ki je lahko posledica klonalne evolucije in selekcijskega pritiska med kemoterapijo. Pri neuspešnem zdravljenju in relapsu rakavih bolezni je ključen dejavnik intratumorska heterogenost (ITH) (43). Večina dosedanjega znanja o ITH izvira iz analize genomskih in transkriptomskih analiz celokupnega genetskega materiala več tumorskih celic, s katerimi dobimo povprečno sliko o prisotnosti genetskih sprememb, ki izvirajo iz različnih subpopulacij tumorskih celic. S takšnimi analizami lahko zato zgrešimo zelo majhne klone, ki lahko kasneje postanejo dominantni in povzročijo relaps ali napredovanje bolezni. Pri raziskovanju klonalne dinamike v ospredje prihajajo nove metode enoceličnega sekvenciranja, s katerimi lahko znotraj posamezne celice hkrati spremljamo izražanje do $10^{4}$ genov. To nam omogoča popolnoma nov in edinstven vpogled v dogajanje znotraj celice, prepoznavanje subklonov $z$ genetskimi spremembami, pomembnimi za relaps, in bistveno boljše razumevanje razlik med posameznimi tumorskimi kloni $(44,45)$.

Že ob postavitvi diagnoze ALL so lahko prisotni subkloni, ki so kasneje odgovorni za relaps in so odporni na zdravljenje s kemoterapijo še pred pridobitvijo sekundarnih genetskih sprememb. Pogosto imajo spremembe v genih CREBBP, NOTCH1 in genih, 
povezanih s signalno potjo RAS. Nekatere genetske spremembe, ki vodijo v relaps, nastanejo šele med kemoterapijo, lahko tudi kot posledica kemoterapije (spremembe $v$ genih NCOR2, USH2A in NT5C2) $(46,47)$. Z genomskimi analizami, tudi enoceličnim sekvenciranjem, lahko spremljamo klonalno dinamiko med zdravljenjem in ob relapsu, kar morda omogoča hitrejše prepoznavanje tistih bolnikov, pri katerih bi bilo smiselno že zgodaj prilagoditi zdravljenje (44).

\section{Uporaba NGS pri spremljanju MRD}

Minimalen preostanek bolezni (angl. minimal residual disease, MRD) je populacija levkemičnih celic, ki preživijo zdravljenje in so v nadaljevanju lahko vzrok za relaps bolezni. Na podlagi vrednosti MRD spremljamo odziv na zdravljenje, določamo intenzivnost in trajanje zdravljenja ter bolnike razvrščamo $v$ različne skupine tveganja za relaps. V Sloveniji prisotnost blastnih celic določamo z metodo pretočne citometrije (angl. flow citometry, FC) v vzorcu kostnega mozga 15. in 33. dan zdravljenja $(48,49)$.

MRD lahko merimo z različnimi metodami, kot sta pretočna citometrija in verižna reakcija s polimerazo, ki ju danes večinoma uporabljamo. Metode za določanje MRD morajo biti točne in občutljive ter omogočati določanje specifičnih označevalcev za ALL (npr. imunofenotip, specifične molekularne spremembe). FC in PCR imata določene pomanjkljivosti (48), zato $v$ ospredje vse bolj prihajajo tudi metode NGS, saj so v primerjavi s prej omenjenima metodama bolj točne in občutljive, relativno hitre in omogočajo zaznavanje različnih genetskih vzorcev in majhnih subklonalnih populacij. To zagotavlja manjše število lažno negativnih rezultatov MRD in hitrejše posredovanje pri bolnikih z večjim tveganjem za relaps. Boljša občutljivost te metode je tudi potencialna možnost spremlja- nja MRD iz periferne krvi, s čimer bi se izognili dodatnim odvzemom kostnega mozga $(49,50)$.

\section{Zaključek}

Hiter razvoj novih metod je omogočil prepoznavanje številnih novih genetskih sprememb, ki so vpletene $\checkmark$ razvoj ALL pri otrocih. To je omogočilo opredelitev številnih novih podtipov otroških ALL in boljšo opredelitev tveganja pri številnih bolnikih, dobili pa smo tudi vpogled $v$ mehanizme, $k i$ so vpleteni v ponovitev bolezni. Vse te novosti so hkrati tudi novi izzivi glede uporabe ogromne količine informacij pri obravnavi bolnikov, saj za nekatere spremembe še nimamo podatkov o njihovem kliničnem pomenu.

RNK sekvenciranja trenutno še ni v smernicah za obravnavo pediatričnih bolnikov z ALL, prav tako ga v Sloveniji še ne uporabljamo v rutinski obravnavi vseh bolnikov. V prihodnosti bo potrebno podrobneje preučiti, katere tarče bi dejansko pripomogle k boljši obravnavi bolnikov, ter pripraviti in standardizirati protokole za rutinsko uporabo NGS pri diagnosticiranju ALL in spremljanju MRD. V Sloveniji poteka molekularnogenetsko diagnosticiranje ALL v dveh laboratorijih, in sicer v Specializiranem hematološkem laboratoriju Univerzitetnega kliničnega centra Ljubljana in na Kliničnem inštitutu za specialno laboratorijsko diagnostiko Pediatrične klinike Ljubljana. Oba laboratorija v prihodnosti načrtujeta uvedbo metod NGS v rutinsko diagnosticiranje za bolj celovito obravnavo bolnikov z ALL.

\section{Literatura}

1. Ward E, DeSantis C, Robbins A, Kohler B, Jemal A. Childhood and adolescent cancer statistics 2014. CA Cancer J Clin 2014; 64(2): 83-103.

2. Jazbec J, Rajić V, Karas Kuželički N. Levkemije otroške dobe. Številka ob 3 kongresu Hematol Transfuziol Slov z Mednar udeležbo2008; suppl I(77): 25-30.

3. Andoljšek D, Černelč P, Mlakar U, Modic M, Pajić T, Podgornik H, et al. Bolezni krvi in krvotvor- nik organov. In: Košnik M, Štajer D, editors. Interna medicina. 5. izdaja. Ljubljana: Medicinska fakulteta, Slovensko zdravniško društvo, Knjigotrštvo Buča d.0.0.2018; 1159-65.

4. Haferlach T, Bacher U, Kern W, Schnittger S, Haferlach C. Diagnostic pathways in acute leukemias: A proposal for a multimodal approach. Ann Hematol 2007; 86(5): 311-27.

5. Campo E, Pileri S, Swerdlow SH, Pileri SA, Harris NL, Stein H et al. WHO Classification of Tumours of the Haematopoietic and Lymphoid Tissues Review Series the updated WHO classification of hematological malignancies; The 2016 revision of the World Health Organization classification of lymphoid neoplasms. Blood 2016; 127(20).

6. Inaba H, Mullighan CG. Pediatric acute lymphoblastic leukemia. Haematologica 2020; Online (11).

7. Ferrando AA, Neuberg DS, Staunton J, Loh ML, Huard C, Raimondi SC et al. Gene expression signatures define novel oncogenic pathways in T cell acute lymphoblastic leukemia. Cancer Cell 2002; $1(1): 75-87$

8. Gianni F, Belver L, Ferrando A. The genetics and mechanisms of T-cell acute lymphoblastic leuke mia. Cold Spring Harb Perspect Med 2020; 10(3).

9. Liu Y, Easton J, Shao Y, Maciaszek J, Wang Z, Wilkinson MR et al. The Genomic Landscape of Pediatric and Young Adult T-lineage Acute Lymphoblastic Leukemia. Nat Genet 2017; 49(8): 1211-8.

10. Weng AP, Ferrando AA, Lee W, Morris IV JP, Silverman LB, Sanchez-Irizarry C et al. Activating mutations of NOTCH1 in human T cell acute lymphoblastic leukemia. Science 2004; 306(5694): 269-71.

11. Palomero T, Wei KL, Odom DT, Sulis ML, Real PJ, Margolin A et al. NOTCH1 directly regulates C-MYC and activates a feed-forward-loop transcriptional network promoting leukemic cell growth. Proc Natl Acad Sci U SA 2006; 103(48): 18261-6.

12. Coustan-Smith E, Mullighan CG, Onciu M, Behm FG, Raimondi SC, Pei D et al. Early T-Cell Precursor Leukemia: A Subtype of Very High-Risk Acute Lymphoblastic Leukemia Identified in Two Independant Cohorts. Lancet 2010; 10(2): 147-56.

13. Vlierberghe P Van, Ambesi-Impiombato A, Perez-Garcia A, Haydu JE, Rigo I, Hadler M et al. ETV6 mutations in early immature human T cell leukemias. J Exp Med2011; 208(13): 2571-9.

14. Zhang J, Ding L, Holmfeldt L, Wu G, Heatley SL, Easton J et al. The genetic basis of early T-cell precursor acute lymphoblastic leukaemia. Nature 2012; 481(7380): 157-63.

15. Mrózek K, Harper DP, Aplan PD. Cytogenetics and Molecular Genetics of Acute Lymphoblastic Leukemia. Hematol Oncol Clin North Am 2009; 23(5): 991-1010.

16. Roberts KG, Reshmi SC, Harvey RC, Chen IM, Patel K, Stonerock E et al. Genomic and outcome analyses of Ph-like ALL in NCl standard-risk patients: a report from the children's oncology group. Blood 2018; 132(8): 815-24.

17. Hunger SP, LuX, Devidas M, Camitta BM, Gaynon PS, Winick NJ et al. Improved survival for children and adolescents with acute lymphoblastic leukemia between 1990 and 2005: A report from the children's oncology group. J Clin Oncol 2012; 30(14): 1663-9. 
18. Einsiedel HG, Von Stackelberg A, Hartmann R, Fengler R, Schrappe M, Janka-Schaub G et al. Long-term outcome in children with relapsed ALL by risk-stratified salvage therapy: Results of trial Acute Lymphoblastic Leukemia-Relapse Study of the Berlin-Frankfurt-Münster Group 87. J Clin Oncol 2005; 23(31): 7942-50

19. Karas Kuželički N. Novi pristopi k zdravljenju akutne limfoblastne levkemije pri otrocih. Farm Vestn 2014; 368-77.

20. Coccaro N, Anelli L, Zagaria A, Specchia G, Albano F. Next-generation sequencing in acute lymphoblastic Leukemia. Int J Mol Sci 2019; 20(12).

21. Zhong Y, Xu F, Wu J, Schubert J, Li MM. Application of Next Generation Sequencing in Laboratory Medicine. Ann Lab Med 2020; 41(1): 25-43.

22. Qin D. Next-generation sequencing and its clinical application. Cancer Biol Med 2019; 16(1): 4-10. 23. Goodwin S, McPherson JD, McCombie WR. Coming of age: Ten years of next-generation sequencing technologies. Nat Rev Genet 2016; 17(6): 333-51.

24. Brown LM, Lonsdale A, Zhu A, Davidson NM, Schmidt B, Hawkins A et al. The application of RNA sequencing for the diagnosis and genomic classification of pediatric acute lymphoblastic leukemia. Blood Adv 2020; 4(5): 930-42.

25. Kim B, Lee H, Shin S, Lee ST, Choi JR. Clinical Evaluation of Massively Parallel RNA Sequencing for Detecting Recurrent Gene Fusions in Hematologic Malignancies. J Mol Diagnostics 2019; 21(1): 163-70. 26. Vega-Garcia N, Benito R, Esperanza-Cebollada E, Llop M, Robledo C, Vicente-Garcés C et al. Helpful criteria when implementing ngs panels in childhood lymphoblastic leukemia. J Pers Med 2020; 10(4): 1-15.

27. Archer ${ }^{\circledast}$. Archer ${ }^{\circledast}$ FusionPlex ${ }^{\circledast}$ NGS Assays and Bioinformatic Analysis 2020; Dostopno na: https:// emea.illumina.com/content/dam/illumina-marketing/documents/products/brochures/archer-fusionplex-ngs-assays-brochure.pdf.

28. Archer $^{\oplus}$. Archer $^{\circledast}$ FusionPlex ${ }^{\circledast}$ Acute Lymphobla stic Leukemia (ALL) Kit. 2018; Dostopno na: https:// dlongwood.com/wp-content/uploads/2019/11/ archer-FusionPlex-ALL_diagnostica-longwood.pdf. 29. Quispe-Tintaya W. Deregulation of DUX4 and ERG in acute lymphoblastic leukemia. Nat Genet 2016; 48(12): 1481-9.

30. Zaliova M, Stuchly J, Winkowska L, Musilova A, Fiser K, Slamova M et al. Genomic landscape of pediatric B-other acute lymphoblastic leukemia in a consecutive European cohort. Haematologica 2019; 104(7): 1396-406

31. Mullighan CG, Alexander TB, Gu Z, lacobucci I, Dickerson K, Choi JK et al. PAX5-driven Subtypes of B-progenitor Acute Lymphoblastic Leukemia. Nat Genet 2019; 51(2): 296-307.

32. Kuiper RP, Waanders E, Van Der Velden VHJ, Van Reijmersdal SV, Venkatachalam R, Scheijen B et al. IKZF1 deletions predict relapse in uniformly treated pediatric precursor B-ALL. Leukemia 2010; 24(7): 1258-64.

33. Dörge P, Meissner B, Zimmermann M, Möricke A, Schrauder A, Bouquin JP et al. IKZF1 deletion is an independent predictor of outcome in pediatric acute lymphoblastic leukemia treated according to the ALL-BFM 2000 protocol. Haematologica 2013; 98(3): 428-32.

34. Stanulla M, Dagdan E, Zaliova M, Möricke A, Palmi C, Cazzaniga G et al. IKZF1 plus defines a new minimal residual disease-dependent very-poor prognostic profile in pediatric b-cell precursor acute lymphoblastic leukemia. J Clin Oncol 2018; 36(12): 1240-9.

35. Lilljebjörn H, Henningsson $\mathrm{R}$, Hyrenius-Wittsten A, Olsson L, Orsmark-Pietras C, Von Palffy S et al. Identification of ETV6-RUNX1-like and DUX4-rearranged subtypes in paediatric B-cell precursor acute lymphoblastic leukaemia. Nat Commun 2016; 7.

36. Den Boer ML, van Slegtenhorst M, De Menezes RX, Cheok MH, Buijs-Gladdines JG, Peters ST et al. A subtype of childhood acute lymphoblastic leukaemia with poor treatment outcome: a genome-wide classification study. Lancet Oncol 2009; 10(2): 125-34.

37. Li JF, Dai YT, Lilljebjörn H, Shen SH, Cui BW, Bai $\mathrm{L}$ et al. Transcriptional landscape of B cell precurso acute lymphoblastic leukemia based on an international study of 1,223 cases. Proc Natl Acad Sci U S A 2018; 115(50): E11711-20.

38. Vicente C, Schwab C, Broux M, Geerdens E, Degryse S, Demeyer S et al. Targeted sequencing identifies associations between IL7R-JAK mutations and epigenetic modulators in T-cell acute lymphoblastic leukemia. Haematologica 2015; 100(10): 1301-10

39. Chang YH, Yu CH, Jou ST, Lin CY, Lin KH, Lu MY et al. Targeted sequencing to identify genetic alterations and prognostic markers in pediatric T-cell acute lymphoblastic leukemia. Sci Rep2021; 11(1): 1-10.

40. Chen B, Jiang L, Zhong ML, Li JF, Li BS, Peng LJ et al. Identification of fusion genes and characterization of transcriptome features in T-cell acute lymphoblastic leukemia. Proc Natl Acad Sci U S A 2017; 115(2): 373-8.

41. Hu S, Oian M, Zhang H, Guo Y, Yang J, Zhao X et al. Whole-genome noncoding sequence analysis in T-cell acute lymphoblastic leukemia identifies oncogene enhancer mutations. Blood 2017; 129(24): 3262-4.

42. Hunger SP, Mullighan CG. Acute lymphoblastic leukemia in children. N Engl J Med 2015; 373(16): 1541-52.

43. McGranahan N, Swanton C. Clonal Heterogeneity and Tumor Evolution: Past, Present, and the Future. Cell 2017; 168(4): 613-28.

44. Brierley CK, Mead AJ. Single-cell sequencing in hematology. Curr Opin Oncol 2020; 32(2): 139-45. 45. Stuart T, Satija R. Integrative single-cell analysis. Nat Rev Genet 2019; 20(5): 257-72.

46. Li B, Brady SW, Ma X, Shen S, Zhang Y, Li Y et al. Therapy-induced mutations drive the genomic landscape of relapsed acute lymphoblastic leukemia. Blood 2020; 135(1): 41-55.

47. Waanders E, Gu Z, Dobson SM, Antić Ž, Vorst D, Jongmans MCJ et al. Mutational landscape and patterns of clonal evolution in relapsed pediatric acute lymphoblastic leukemia. Blood Cancer Discov 2020; 1(1): 96-111.

48. Prelog T, Jazbec J. Pomen Določanja Minimalne Rezidualne Bolezni Pri Zdravljenju Akutne Limfoblastne Levkemije $V$ Pediatriji Importance of the Determination of Minimum Residual Disease in Treatment of Acute Lymphoblastic Leukaemia in Paediatrics. 2010;150-5.

49. Kruse A, Abdel-Azim N, Kim HN, Ruan Y, Phan $\mathrm{V}$, Ogana $\mathrm{H}$ et al. Minimal residual disease detection in acute lymphoblastic leukemia. Int J Mol Sci 2020; 21(3): 1054.
50. Logan AC, Vashi N, Faham M, Carlton V, Kong $\mathrm{K}$, Buno I et al. Immunoglobulin and T-cell receptor gene high-throughput sequencing quantifies minimal residual disease in acute lymphoblastic leukemia and predicts post-transplant relapse and survival. Biol Blood Marrow Transplant 2014; 20(9): 1307-13.

\section{Klementina Črepinšek, mag. lab. biomed.}

(kontaktna oseba / contact person)

Klinični inštitut za specialno laboratorijsko diagnostiko, Pediatrična klinika, Univerzitetni klinični center Ljubljana, Vrazov trg 1, 1000 Ljubljana, Slovenija e-naslov: klementina.crepinsek@kclj.si

doc. dr. Maruša Debeljak, spec. lab. med. gen.

Klinični inštitut za specialno laboratorijsko diagnostiko, Pediatrična klinika, Univerzitetni klinični center Ljubljana, Ljubljana, Slovenija

izr. prof. dr. Janez Jazbec, dr. med. Klinični oddelek za hematologijo in onkologijo, Pediatrična klinika, Univerzitetni klinični center Ljubljana, Ljubljana, Slovenija

prispelo / received: 10.6. 2021

sprejeto / accepted:22.9. 2021

Črepinšek K, Debeljak M, Jazbec J. Sekvenciranje naslednje generacije pri obravnavi otrok z akutno limfoblastno levkemijo. Slov Pediatr 2021; 28(4): 183-188. https://doi.org/10.38031/ slovpediatr-2021-4-01. 